\title{
Hydrosedimentological Dynamic on Água Fria Watershed
}

\author{
Alexandre Marco da Silva ${ }^{1} *$ and Harry Edmar Schulz ${ }^{2}$ \\ ${ }^{I}$ Departamento de Engenharia Ambiental; Campus Experimental de Sorocaba; Universidade Estadual Paulista; \\ Av. 3 de março, 511; Altos da Boa Vista; 18087-180; amsilva@sorocaba.unesp.br; Sorocaba - SP - Brasil. \\ ${ }^{2}$ Departamento de Hidráulica e Saneamento; Escola de Engenharia de São Carlos; Universidade de São Paulo; \\ São Paulo - SP - Brasil.
}

\begin{abstract}
This study aimed surveying the amount of sediment yielded from the Água Fria watershed (Palmas, Tocantins, Brazil), from February-1998 to January-1999, and investigating the relations between the sediment yield and some environmental and/or antropic factors. The Colby's method was the technique employed for this investigation. The specific sediment yield and sediment delivery ratio were also determined for this period. It was estimated that 138,619 tons of sediment were yielded and the specific sediment yield for the study area was $827 \mathrm{t} \mathrm{km}^{-2} \mathrm{y}^{-1}$, while the sediment delivery ratio was $6.2 \%$. The suspended load was the most dominating fraction in almost all the studied period.
\end{abstract}

Key words: Sediment yield, sediment delivery ratio, watershed

\section{INTRODUCTION}

Rivers are landscape integrating components and receive the whole load of transported material from the drainage basin in which they are inserted (Silva et al., 2001). Then, it is possible to affirm that land cover and water resources quality are unequivocally linked. The land use changes often implicate in the degradation of the water quality of the superficial water bodies of the watershed. Water quality is also related with the level of control of the pollution sources (Tucci, 1997; Marques et al., 2003). Careful planning and land use polices that contemplate the protection of streams, rivers, and their respective riparian zones, can be implemented in order to balance the economic development and the protection of the natural environment. Developing actions that take place without such considerations, however, can lead to significant degradation of streams and ground water, and loss of river water quality (Guiraud et al., 2004).

The production and transportation of sediment in a watershed is influenced by a set of complex environmental factors that vary temporally and spatially. One of these factors is the soil erosion, which is caused mainly by rainfall and overland flow. Land use practices such as logging and clearing, grazing, road construction, agriculture, and urbanization activities also affect sediment production and sediment delivery from a watershed (Nelson and Booth, 2002). However, few studies have been conducted on sediment transport in Brazil, because most of the consequences are not immediate, and commonly there is a disbelief and indifference in the people (Carvalho, 1994).

Sediment yield (SY) is the total mass of sediment in suspension and bed load that reaches the exit of a drainage basin. The SY is related to many

\footnotetext{
${ }^{*}$ Author for correspondence
} 
factors, according to the considered scale. In continental or worldwide scale, climate is the dominant control; slope and human activity are of secondary importance (Haan et al., 1994). For regional scale where climate is relatively uniform, other factors control variation in sediment yield: 1 . Lithology. SY is positively correlated with the rock erodibility. 2. Topography. SY is negatively correlated with drainage area, but this is generally because other variables, such as precipitation and relief, also vary with drainage basin area. Also, the sediment storage increase as drainage area increases. 3. Vegetation and land use. The relationship between SY and vegetation reflects the relation between SY and climate (for pristine areas). Land use can have very important effects on SY. In some cases this variable can overwhelm other variables as a control of spatial variations in SY (Carvalho, 1994).

Sediment will normally have numerous opportunities to be deposited between the field and point of final deposition, reducing the sediment yield accordingly (Haan et al., 1994). A sediment delivery ratio (SDR) has been used to quantify the amount of deposition that occurs in a watershed. One manner to estimating the SDR is through the Equation 1.

$$
\mathrm{SDR}=\frac{\mathrm{SY}}{\mathrm{GE}} \times 100
$$

Where:

SDR - Sediment delivery ratio, in \%;

$\mathrm{SY}$ - sediment yield, in $\mathrm{t} \mathrm{year}^{-1}$;

$\mathrm{GE}$ - gross erosion, in $\mathrm{t} \mathrm{year}^{-1}$.

Gross erosion is composed of rill and interrill erosion, gully erosion, and stream erosion. On disturbed areas, sheet and rill erosion are the principal components of gross erosion (Haan et al., 1994). The SDR is negatively correlated with drainage basin area due to: 1. Natural factors: storage of sediment in the drainage basin increases with area because relief declines downstream and hillslopes develop wider concave foot-slopes and broader floodplains. 2. Human factors: dams on rivers trap sediment of water and reduce the transference of the flow remaining in the channel (Carvalho, 1994 and 1998).

Considering all these factors, large variation of sediment yield for the watersheds along the world has been noticed. Sediment yields of $40 \mathrm{t} \mathrm{km}^{-2} \mathrm{y}^{-1}$ for
Nam Pua watershed (Thailand) to $13,300 \mathrm{t} \mathrm{km}^{-2} \mathrm{y}^{-1}$ for Cleddau watershed (New Zealand) have been reported for watersheds ranging from 140 to 170 $\mathrm{km}^{2}$ (FAO, 2001). Enger and Smith (1995) reported average sediment yield values of $612 \mathrm{t} \mathrm{km}^{-2} \mathrm{y}^{-1}$ for the Amazon region.

The aim of this study was to investigate the relationship between the hydrosedimentological dynamic and water quality for the Água Fria watershed (Palmas - Tocantins - Brazil).

\section{The Study Site}

\section{Localization and environmental characteristics}

The study area, Água Fria watershed, has an area of $167.6 \mathrm{~km}^{2}$ and is fully inserted in the municipal area of Palmas (Tocantins, Brazilian northern region). The geographical coordinates are: $48^{\circ} 16^{\prime}$ and $48^{\circ} 23^{\prime}$ west longitude and $10^{\circ} 03^{\prime}$ and $10^{\circ} 20^{\prime}$ south latitude (Silva, 1999). Fig. 1 shows the spatial localization of the study area in Brazilian territory. The climate is tropical. The average annual temperature is $24^{\circ} \mathrm{C}$ and average annual rainfall depth is $1,300 \mathrm{~mm}$ (Nimer, 1979). Annual rainfall erosivity is estimated as 5,954.67 MegaJoule $\mathrm{mm} \mathrm{ha}^{-1} \mathrm{~h}^{-1}$ year $^{-1}$, with a low variation among the years $(<15 \%)$ (Silva, 1999). Table 1 shows the monthly values of the rainfall depth and monthly rainfall erosivity recorded for the study period, obtained from Silva and Schulz (2002).

The Água Fria watershed is composed of three main streams: Brejo Comprido, Suçuapara and Água Fria, and its drainage density is greater on the higher elevations of the watershed. The general (average) value for drainage density of the whole area is $0.708 \mathrm{~km}$ of river km $\mathrm{km}^{-2}$. The Água Fria is a third order stream and is a sub watershed of the Tocantins drainage basin. Silva (1999) reported values of water flow (water going from Água Fria stream to Tocantins river) from $0.16 \mathrm{~m}^{3} \mathrm{~s}^{-1}$ (recorded in October-1998) to $12.61 \mathrm{~m}^{3} \mathrm{~s}^{-1}$ (recorded in March-1998), as shown in Table 1. The author also estimated that $33 \%$ of the water precipitated on the watershed was lost by surface runoff.

The altitude in the watershed ranges from $190 \mathrm{~m}$ to $710 \mathrm{~m}$ above the sea level and the predominant class of slope is $1-3 \%$, showing a relief predominantly plane. The slope of the Água Fria watershed is steep on the headwater regions (higher elevations of the watershed) and smoothly waved - plane on the middle parts and near of the estuary of the Água Fria stream (near the 
Tocantins river). Geologic basement is crystalline in the steepest region, and in regions where the relief varies from smoothly waved to plane, the geologic basement is sedimentary (RadamBrasil,
1981). Fig. 2 shows a panoramic view of the watershed and the aspect of the topography of the region.

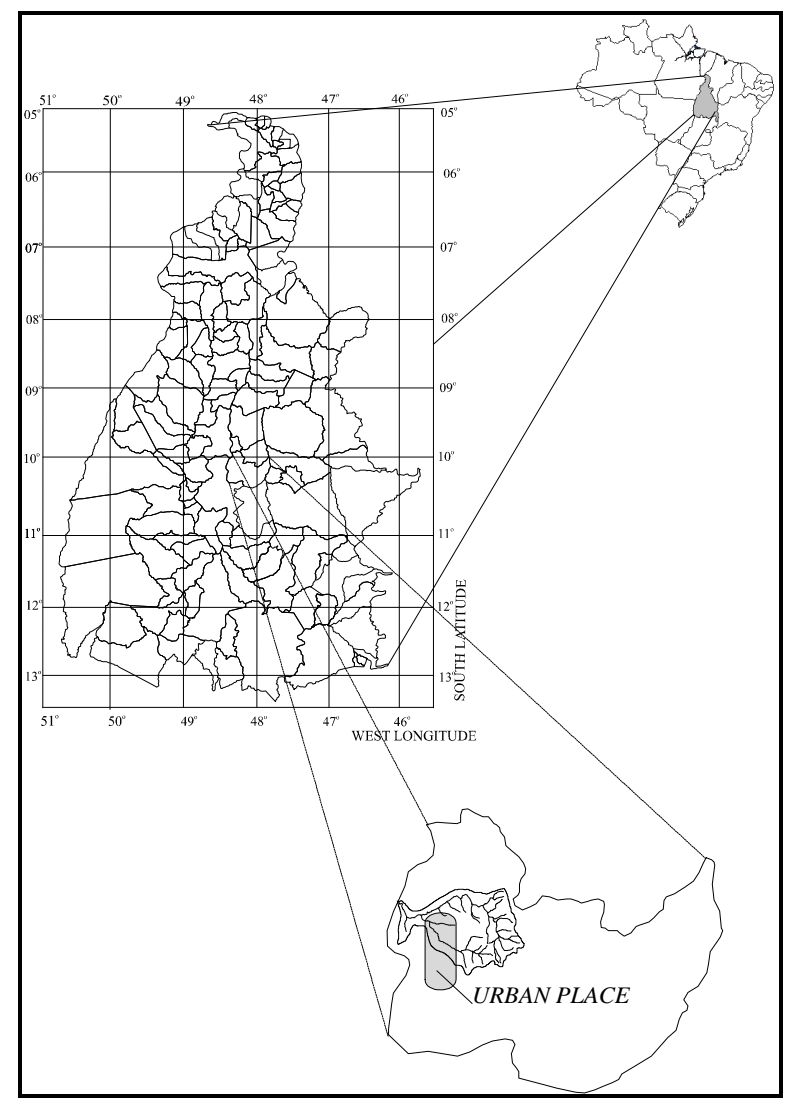

Figure 1 - Spatial localization of the study area (within the Palmas municipal perimeter). Source: Silva (1999)

$\underline{\text { Table } 1 \text { - Monthly values of rainfall depth, rainfall erosivity and flow for the study area. }}$

\begin{tabular}{cccc}
\hline Month & Rainfall & Erosivity & Flow \\
\hline Feb/98 & 232.2 & 901.5 & 5.9 \\
Mar & 338.7 & 940.7 & 12.6 \\
Apr & 84.0 & 562.1 & 3.5 \\
May & 45.9 & 170.6 & 3.1 \\
Jun & 14.1 & 45.1 & 1.2 \\
Jul & 0.0 & 0.0 & 0.8 \\
Aug & 0.0 & 0.0 & 0.6 \\
Sep & 15.7 & 194.2 & 0.2 \\
Oct & 69.8 & 582.7 & 0.1 \\
Nov & 305.1 & 720.0 & 3.3 \\
Dec & 238.0 & 924.1 & 2.7 \\
Jan/99 & 428.6 & 913.3 & 4.8
\end{tabular}

Units: Rainfall depth (mm), rainfall erosivity (MegaJoule. $\mathrm{mm} \mathrm{ha}^{-1} \mathrm{~h}^{-1}$ year $\left.{ }^{-1}\right)$, flow $\left(\mathrm{m}^{3} \mathrm{~s}^{-1}\right.$ ) Source: Silva and Schulz (2002). 


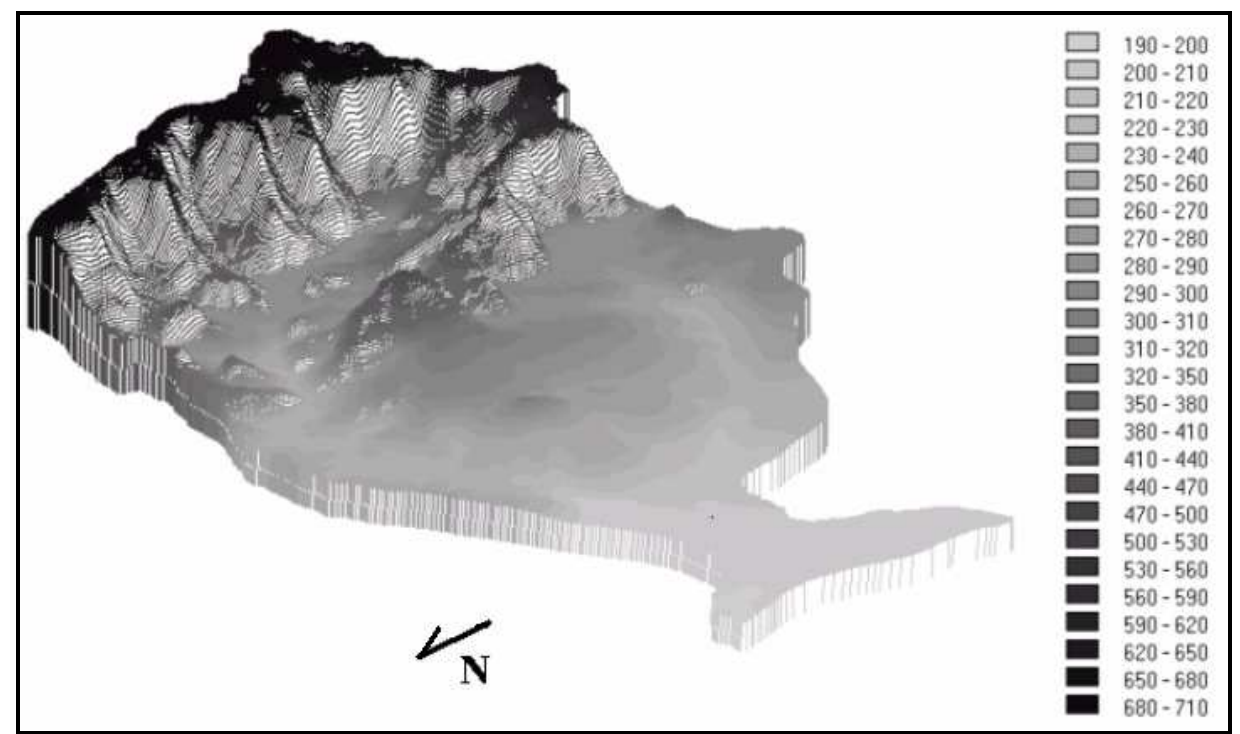

Figure 2 - Panoramic view of the Água Fria watershed. The legend also shows the altitude range (in meters) of watershed (Silva, 1999)

The soil classes occurring in study area were determined by Ranzani (1998), and were, according to F.A.O. classification system: Plinthosol, found on $27.8 \%$ of the whole area; Rhodic Ferralsol (28.0\%); Leptosol (10.3\%); Xanthic Ferralsol (17.3\%); Cambissol (8.0\%); Gleysol (7.6\%). On the watershed (in the most steep regions), bare rock was $1.0 \%$ of the whole area. The predominant vegetation type on the region was the tropical savanna (Cerrado), in a still undisturbed area (RadamBrasil, 1981). A mesophytic forest (in waved areas in headwaters's downstream) was found on the Lajeado's hill. Riparian forest also occurred along some streams of the region. All the vegetation clearly suffered, every year the influence of the dry season (normally from April to September), especially the herbaceous vegetation, mainly due to dry soil conditions.

\section{Land cover}

On the watershed, the following classes of land cover were mapped (Silva, 1999): remnant natural vegetation $(21.5 \%)$; water bodies $(0.3 \%)$; green urban gardens $(0.6 \%)$; build-up $(0.5 \%)$; roads (0.4); bare soil (1.3\%); dirty field $(23.5 \%)$; clean field $(26.0 \%)$; bare rock (1.1\%); burnt areas $(6.7 \%)$ and sparse field (18.2\%).

\section{METHODS}

The sediment yield was determined using the Colby's simplified method (Carvalho, 1994 and Tavares, 1986). The following equations were used:

$\mathrm{Q}_{\mathrm{ST}}=\mathrm{Q}_{\mathrm{SM}}+\mathrm{Q}_{\mathrm{NM}}$

$\mathrm{Q}_{\mathrm{SM}}=0.0864 \times \mathrm{Q} \times \mathrm{C}^{\prime} \mathrm{S}$

$\mathrm{Q}_{\mathrm{NM}}=\mathrm{q}^{\prime}{ }_{\mathrm{nm}} \times \mathrm{K} \times \mathrm{L}$

Where:

$Q_{S T}-$ Total sediment yield, in $\mathrm{t} \mathrm{day}^{-1}$.

$Q_{S M}$ - Quantified solid discharge, in t day ${ }^{-1}$.

$Q_{N M}$ - Not quantified solid discharge, in t day ${ }^{-1}$.

$Q$ - Water flow, in $\mathrm{m}^{3} \mathrm{~s}^{-1}$.

$C^{\prime}{ }_{s}$ - Quantified concentration of sediment, in parts per million.

$L$ - Channel width, in meters.

$q_{n m}^{\prime}$ - Not quantified solid discharge (estimated according to the width of the drainage channel).

$K-$ Factor of correction.

The "q' $n m$ " and " $K$ " components of the equations were computed using three abacuses that required information about water flow velocity of the drainage channel, average depth of the channel and sediment concentration (Carvalho, 1994). Hence, the required information from the gauging station were: 1) sediment concentration, 2) average 
depth of the channel, 3) channel width and 4) average flow velocity in the drainage channel.

SEDIMENT CONCENTRATION: Three samples were collected each month from February 1998 to January 1999 on a gauging station located on the Água Fria stream about $50 \mathrm{~m}$ before the joining of Água Fria river and Tocantins river. The samples were collected in the middle of the channel, from surface to bed, by using the "vertical integration method" (Carvalho, 1994). The samples were transported to laboratory of Universidade do Tocantins (UNITINS) and there the concentration of sediment was determined using the evaporation method (Carvalho, 1994; Eaton et al., 1995; Pião, 1995). The residue after evaporation was quantified in ppm, as required by the Colby's method.

AVERAGE DEPTH: it was determined monthly through the elaboration of the profile of the channel (bathymetry) at the same point of water sampling. Using the bathymetric data, the area of the channel and the average depth were computed. CHANNEL AVERAGE WIDTH: it was determined by the quantification of the width of the drainage channel at the water/sediment sampling point.

FLOW VELOCITY: it was determined by the float method (Pião, 1995). A float was launched from one pre-determined point upstream, when the float crossed the determined point upstream a chronometer was turned on, when the float crossed the determined point 10 meters downstream, the chronometer was turned off and the time was recorded. This operation was executed ten times on each month (even using the same upstream and downstream points). The average time was determined by computing the arithmetic average of the ten previously recorded values and the average flow velocity was calculated by division between the average time and the 10 meters length considered. With all these information, both the liquid and solid discharge on that point and at that time were estimated using the abacuses (Carvalho, 1994, equations 2, 3 and 4). After the determination of the sediment yield on the point for each month, the average value of sediment yield for that period (month) was calculated by using the value of the current month and the value of the subsequent month (for example, to determine the average value for June, the values of June and July were used, and so on).

As the value was in t.day ${ }^{-1}$, the average value obtained for each month was multiplied by the number of days of that month. For example: the average value obtained for April (average between $418.3 \mathrm{t} \mathrm{day}^{-1}$ and $406.9 \mathrm{t} \mathrm{day}^{-1}$, respectively for April and May) was $412.6 \mathrm{t} \mathrm{day}^{-1}$. Multiplying $412.6 \mathrm{t} \mathrm{day}^{-1} \times 30$ days, the resulting value for April was 12,378.0 t month ${ }^{-1}$ of sediment yielded from the Água Fria watershed. The specific production of sediment was determined according to equation described in Carvalho (1994) and Haan et al. (1994) (equation 5).

$$
\operatorname{SpSY}=\frac{\mathrm{SY}}{\mathrm{A}}
$$

Where:

SpSY - specific sediment yield $\left(\mathrm{t}\right.$ year $\left.{ }^{-1} \mathrm{~km}^{-2}\right)$. $\mathrm{SY}$ - sediment yield $\left(\mathrm{t}_{\mathrm{year}} \mathrm{r}^{-1}\right)$.

A - Watershed area $\left(\mathrm{km}^{2}\right)$.

The sediment delivery ratio was computed according to equation 1, described by Wischmeier and Smith (1978) and by Haan et al. (1994). The value of the gross erosion for the study area was obtained from Silva (1999) who utilized the Universal Soil Loss Equation (Wischmeier and Smith, 1978) on the estimates.

\section{RESULTS AND DISCUSSION}

Fig. 3 shows the monthly sediment yield and monthly specific sediment yield for the study area. It was estimated that 138,619 tons of sediment were yielded during the period of study. Comparatively, for the Itiquira river (Paraguai river basin - Mato Grosso do Sul State) M.M.A. (1997) found 254,520 t year ${ }^{-1}$ of sediment also in one year. Kusumandari and Mitchell (1997) recorded an average value of $256,500 \mathrm{t} \mathrm{year}^{-1}$ of sediment carried out for the Citarum River basin (Indonesia) during 1991-1992.

The specific sediment yield (SY) for the study area was $827 \mathrm{t} \mathrm{km}^{-2}$ year ${ }^{-1}$, a little higher than that estimated by Enger and Smith (1995) for the Amazon region $\left(612 \mathrm{t} \mathrm{km}^{-2}\right.$ year $\left.^{-1}\right)$ and higher than the specific yield for entering Brazil showed by Bordas (1998): $470 \mathrm{t} \mathrm{km}^{-2}$ year ${ }^{-1}$. Fig. 4 shows a curve of sediment yield versus drainage area, obtained from Carvalho (1994) and with the value found on this study inserted on it. It was noticed that the value for the study area was located below the "general sediment yield curve", despite being 
classified as high, according to the interpretation chart proposed by the author. On this chart (Fig. 4) it was noticed that the value of sediment yield diminished as the drainage area increased.
Between the field and point of final deposition, sediment normally would have numerous opportunities to be deposited, reducing the sediment yield accordingly (Haan et al., 1994).

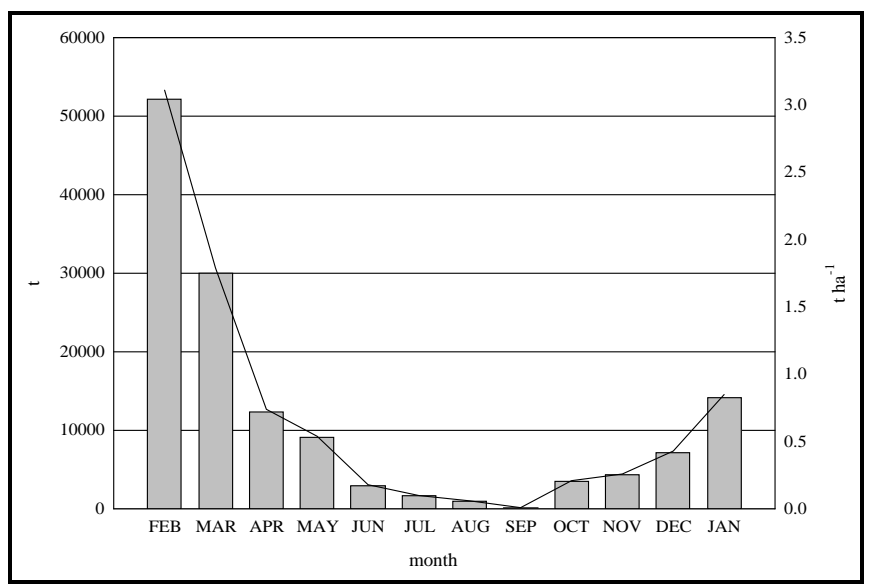

Figure 3 - Monthly sediment yield (left axis - bars) and monthly specific sediment yield for study area

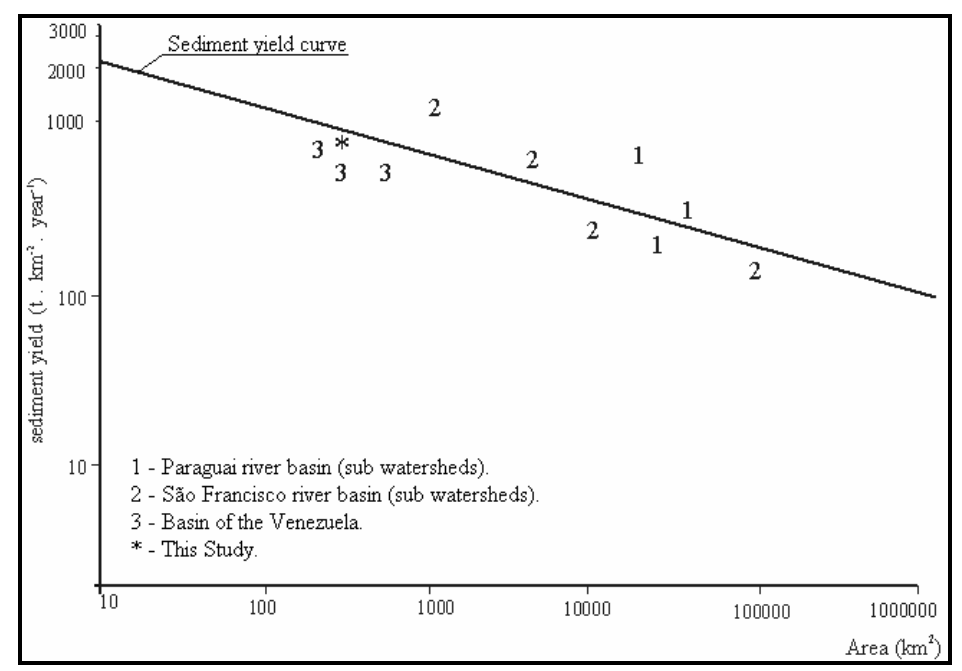

Figure 4 - Sediment yield versus drainage area, sediment yield curve and some values (points) obtained from Carvalho (1994) and Haan et al. (1994) with the value found on this study

Strong irregularity on the seasonal amount of sediment carried out of the watershed was observed. Resulting correlation analysis between the monthly sediment yield and the monthly water flow (water flow data obtained from Silva, 1999) was $r^{2}=0.88 \quad$ (significant $\alpha=1 \%$ ). Significant correlation between monthly sediment yield and monthly average speed of the stream $\left(\mathrm{r}^{2}=0.46\right.$, significant $\alpha=5 \%$ ) was also observed. However, the correlation between the monthly sediment yield and monthly rainfall depth was not significant, being significant the relation between the monthly sediment yield and the monthly rainfall erosivity $\left(r^{2}=0.37\right.$, significant $\left.\alpha=5 \%\right)$.

The relation between water flow and sediment yield is shown in Fig. 5. The " $r$ " value was 0.94 and the equation generated was $y=42.723 x^{1.3819}$. The " $r$ " found on this study was significant and 
presented better performance as that one showed by Carvalho (2000) for the Itiquira river $\left(r^{2}=0.32\right.$ and 0.66 for 1979-1980 and 1981-1982 hydrologic years, respectively). Filizola et al. (1999) also found a low and unsatisfactory value for " $\mathrm{r}$ " for the Madeira river $\left(r^{2}=0.21\right)$, unlikely that one found by Martinelli et al. (1993) for the same river and for the same gauging station. Filizola et al. (1999) reported a difference on the estimative because the short amount of available information used. In fact, the short amount of hydrosedimentometric data normally has been one of the major problems that impede the development of good and precise studies in Brazil, as also affirmed by Carvalho (1994).

Fig. 6 shows the variation of the proportion of the suspended and bed load fractions of sediment for the study area along the study period, determined through the Colby's method (respectively, Q $\mathrm{QSM}_{\mathrm{SM}}$ and $\mathrm{Q}_{\mathrm{NM}}$ parameters of the equation 2). It was noticed that the temporal variation of the proportion of suspended sediment load did follow neither the seasonality of the water discharge nor the seasonality of the rainfall erosivity. The general average proportion of suspended material was of $70.7 \%$ (variation coefficient $26.8 \%$ ) and the final average proportion of bed material was of 29.3\% (variation coefficient $64.7 \%$ ). Christofoletti (1981) showed the proportions of total sediment for some European/Asiatic rivers and most of them had a proportion of bed sediment smaller than $10 \%$, despite the mountainous rivers of the Alps presenting $30 \%$ or more of bed material.

Silva (1999), using the Universal Soil Loss Equation (Wischmeier and Smith 1978), estimated the amount of soil loss for the study period (gross erosion): $2,239,955.0 \mathrm{t}$ and by applying the equation 1 , the value found for the sediment delivery ratio for the Água Fria was 6.2\%.
Comparatively, in "Alto Paraguai" watershed values ranging from 1.9 to $7.0 \%$ were estimated for eight sub-watersheds whose drainage area ranged from 5.1 to $57.7 \mathrm{~km}^{2}$ (M.M.A., 1997). Through field visits during the study period, it was reported that the remnant riparian vegetation (relicts), located along the watercourses of the watershed, played an important role on the sediment yield and transportation. It was noticed that the roles of the riparian vegetation were mainly 1) "Filtering" the water mass of the streams - in some parts of the streams, where there was significant portions of riparian vegetation, this vegetation have been retaining part of the sediment of the stream and the water passing through the vegetation flows a little cleaner than before. 2) Protecting the stream against the streambank erosion - in some parts along the streams without riparian vegetation it was easily observed that the geometry of the channel was totally altered due to stream erosion. Water quality is maintained by riparian vegetation through many ways, including the stabilization of slopes and stream banks by networks of tree roots that help prevent erosion, act as filter pollutants, metabolize nutrients, and trap sediment, as reported and detailed by Vought et al. (1995).

During the period of study, in Água Fria watershed, there were multiple land cover types and proposals, mainly the urbanization goals, many of them presenting potential of degradation of the riparian vegetation and/or exposing the soil surface to erosive process. Respecting the Brazilian Forest Code in order to provide an excellent conservation state of the riparian vegetation would be a crucial strategy for a regional sustainable development and avoiding environmental and urban problems related to erosion / sediment. 


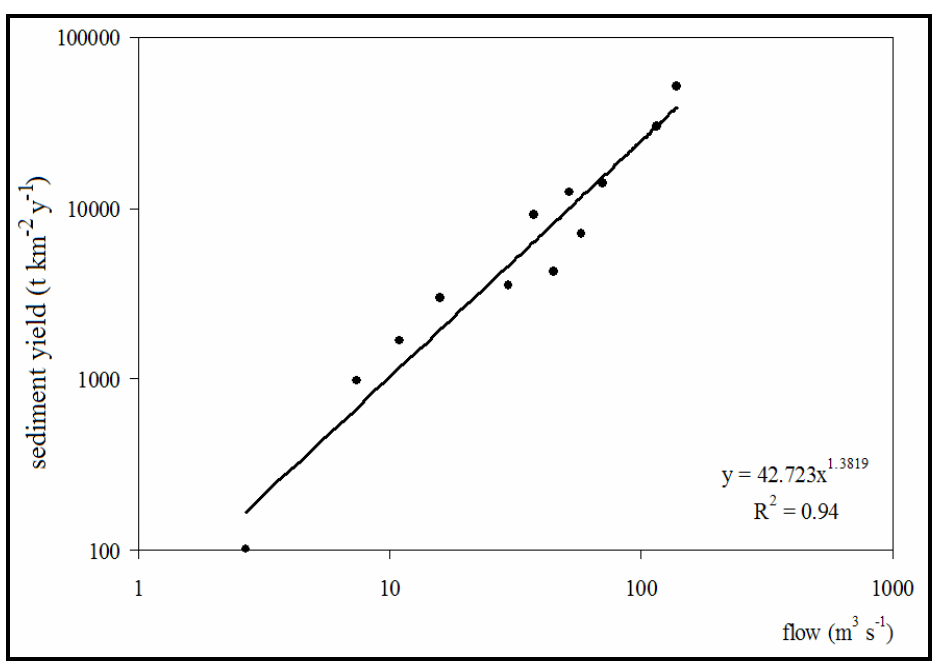

Figure 5 - Sediment yield versus flow for Água Fria watershed

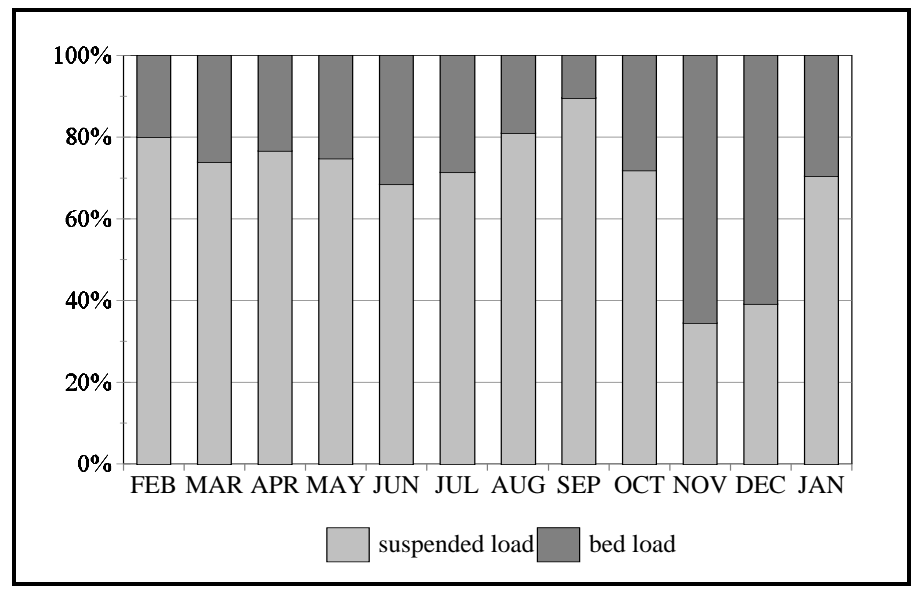

Figure 6 - Proportions of suspended and bed loads for the study area

\section{CONCLUSIONS}

The annual sediment yield for the study area between February-1998 and Jannuary-1999 was 138,619 tons of sediment and the specific sediment yield for the study area was $827 \mathrm{t} \mathrm{km}^{-2}$ year $^{-1}$. The estimated sediment delivery ratio was $6.2 \%$. The suspended load was the predominating fraction in almost all study period, except during November and December, where the bed load fraction predominated. It could be concluded that the state of the riparian vegetation during the study period was the main factor that determined the amount of sediment that were delivered by the water courses or were deposited along the vegetation strips.

\section{ACKNOWLEDGEMENTS}

We thank Odo Primavesi and Hélio do Prado for helping us to translate the soil classes from the Brazilian to the International System (F.A.O.).

\section{RESUMO}

Este estudo objetivou estimar a quantidade de sedimento que foi carreada da microbacia do Ribeirão Água Fria (Palmas, TO) entre fevereiro de 1998 e janeiro de 1999. Almejou-se ainda investigar as relações entre a produção de 
sedimento e alguns fatores antrópicos e ambientais. O método de Colby foi a técnica empregada no estudo. A produção específica de sedimento e o coeficiente de remoção de sedimentos foram parâmetros também investigados neste trabalho. Foi estimada uma quantidade de 138.619 toneladas de sedimento produzido e a produção específica de sedimentos foi estimada como sendo $827 \mathrm{t} \mathrm{km}^{-2} \mathrm{ano}^{-1}$, enquanto que o coeficiente de remoção de sedimentos foi $6,2 \%$. A fração suspensa foi a predominante durante quase todo o período de estudo.

\section{REFERENCES}

Bordas, M. P. (1998), An outline of hydrosedimentological zones in the Brazilian Amazon basin (electronic publication). UNESCO. Web site address: www.unesco.org.uy/phi/libros/manaos/14.html.

Carvalho, N. O. (1994), Hidrossedimentologia Prática. CPRM - Companhia de Pesquisa em Recursos Minerais. Rio de Janeiro - RJ, Brazil.

Carvalho, N. O. (1998), Assoreamento e proteção de reservatórios. Proceedings of the $6^{\text {th }}$ National Symposium of Erosion Control. Presidente Prudente, SP - Brazil. (CD-rom).

Carvalho, N. O. (2000), Guia de avaliação de assoreamento de reservatórios. Brasília - DF. ANEEL. Brazil.

Christofoletti, A. (1981), Geomorfologia Fluvial. Editora Edgard Blücher. São Paulo - SP, Brazil.

Eaton, A. D.; Clesceri, L. S.; Greenberg, A. E. (1995), Standard Methods for examination of water and waster water. $19^{\text {th }}$ edition. Maryland - USA.

Enger, E. D.; Smith, B. F. (1995), Environmental Sciences $-A$ study of Interrelationships. $5^{\text {th }}$ Edition. Wm Brown Publishers. USA.

F.A.O. (2001), World River Sediment Yields Database. Web site address: http://www.fao.org/ag/agl/aglw/sediment

Filizola, N.; Guyot, J. L.; Boaventura, G. (1999), Fluxo de sedimentos em suspensão na Amazônia - uma análise a partir da base de dados da ANEEL. Electronic publication. 9 p. Web site address:

http://www.ana.gov.br/hibam/publicacoes/filizola_1.pdf Guiraud, D. M. C.; Lenzi, E.; Luchese, E. B.; Fávero, L. O. B. (2004), Loss of Macronutrients (N, P, K) in the Hydrographic Basin of the River Ivaí, an Affluent of the River Paraná. Braz Arch Biol Tech., 47, 649 658.
Haan, C. T.; Barfield, B. J.; Hayes, J. C. (1994), Design Hydrology and Sedimentology for Small Catchments. Academic Press - USA.

Kusumandari, A.; Mitchell, B. (1997), Soil erosion and sediment yield in forest and agroforestry areas in West Java, Indonesia. J. Soil Water Conserv. 52,376 380 .

Marques, P. H. C.; Oliveira, H. T.; Machado, E. C. (2003), Limnological study of Piraquara River (Upper Iguaçu Basin): Spatiotemporal variation of physical and chemical variables and watershed zoning. Braz Arch Biol Tech, 46, 383 - 394.

Martinelli, L. A.; Forsberg, B. R.; Victoria, R. L.; Devol, A. H.; Mortatti, J.; Ferreira, J. R.; Bonassi, J.; De Oliveira, E. (1993), Suspended sediment load in the Madeira River. Mitt. Geol.-Paänont. Inst. Univ. Hamburg, Sonderband, 74, 41-54.

M.M.A. - Ministério do Meio Ambiente e da Amazônia Legal. (1997), Plano de Conservação da Bacia do Alto Paraguai. Volume II - tomo II-A Sedimentologia. Brasília - DF. Brazil.

Nelson, E. J.; Booth, D. B. (2002), Sediment sources in an urbanizing, mixed land-use watershed. $J$ Hydrology, 264, 51-68.

Nimer, E. (1979), Climatologia do Brasil. Série Recursos Naturais e Meio Ambiente, no ${ }^{-}$. Fundação IBGE. Brazil.

Pião, A. C. (1995), Transporte de nitrogênio, fósforo e sedimentos pelo Ribeirão dos Carrapatos (Município de Itaí - SP), sua relação com usos do solo e outros impactos antropogênicos e a sua deposição no braço do Taquari (Represa de Jurumirim). Doctorate thesis. Escola de Engenharia de São Carlos USP. São Carlos, SP, Brazil.

RadamBrasil, Projeto. (1981), Levantamento dos recursos naturais. Folha SC 22 - Tocantins, Rio de Janeiro, RJ, Brazil.

Ranzani, G. (1998), Mapa de solos do município de Palmas - TO. Escala 1:100.000. Palmas - Tocantins. (unpublished) - Brazil.

Silva, A. M. (1999), Aplicações de técnicas de geoprocessamento no estudo das relações entre os processos erosivos e sedimentológicos de bacia hidrográfica. São Carlos. EESC-USP. (Doctorate thesis). São Carlos-SP, Brazil.

Silva, A. M; Schulz, H. E. (2002), Determinação dos valores dos fatores da Equação Universal de perda de solo para bacia hidrográfica do Ribeirão Água Fria (Palmas, TO). Geociências, 21: 129-138.

Silva, M. A. L.; Calasans, C. F.; Ovalle, A. R. C.; Rezende, C. E. (2001), Dissolved nitrogen and phosphorus dynamics in the lower portion of the Paraíba do Sul River, Campos dos Goytacazes, RJ, Brazil, Braz Arch Biol Tech, 44, 365 - 371. 
Tavares, A. C. (1986), A erosão dos solos no contexto da análise ambiental - $O$ exemplo do alto curso do Rio São José dos Dourados. São Paulo. Faculdade de Filosofia, Ciências e Letras. (Doctorate Thesis). São Paulo-SP (Brazil).

Tucci, C. E. M. (1997). Hidrologia: Ciência. e Aplicação. Editora da Universidade/ABRH, Porto. Alegre, RS. 450p.

Vought, L. B.M.; Pinay, G.; Fuglsang. A.; Ruffinoni, C. (1995), Structure and function of buffer strips from a water quality perspective in agricultural landscapes. Landscape and Urban Planning, 31, 323 - 331.

Wischmeier, W. H.; Smith, D. D. (1978), Predicting rainfall erosion losses. A guide to conservation planning. Supersedes Agriculture Handbook n⿳o 282. Science and Education Administration United States Department of Agriculture. USA.

Received: March 13, 2006; Revised: August 10, 2006; Accepted: March 23, 2007. 